\title{
Application of Interaction Teaching Method in College English Listening Teaching
}

\author{
Xu Yiqun \\ Foreign Language Department \\ Jilin Business and Technology College \\ Changchun, China \\ 182076127@qq.com
}

\begin{abstract}
The thesis begins with the definition of interaction teaching. Interaction teaching must focus on students. The learners home and abroad all come up with the definition of interaction teaching. Then it puts forward the application procedures, application backgrounds, and specific example of interaction teaching. Interactive teaching is divided into three steps: pre-listening, listening and post-listening. And the author explains how the interaction teaching works with a case. It also analyzes the language input and language output model. There are three factors affecting listening. The first is listeners' factor. The second is speakers' factor. The third is spreading medium and media factor. At last, it concludes with a case of interactive teaching in the listening teaching of college English. The readers can know interaction teaching better and the teachers who read this article can know how to practice interaction teaching.
\end{abstract}

Keywords-college English; listening teaching; interactional teaching method

\section{INTRODUCTION}

Interaction teaching emphasized that language must focus on students. Teachers create real and natural language environment, provide real and meaningful language materials, and make students conduct more meaningful study. The teaching process develops around the certain task of language function.

The theory foundation of interaction teaching mainly includes function language theory, communication ability theory and constructivism theory. Function language theory thinks that language is the system to express meaning not to produce construction. It forms the angle of the application of language, puts forward that language has three main meta functions: social function, conception function, and passage function. Interaction teaching's feature is based on social theory, emphasizes the improvement of students' communicative abilities, and develops the language application abilities of students[1].

Interaction teaching is also called interactive teaching. It is a teaching theory and strategy adapted to modern society. Compared with the model focusing on teachers and students' passive attending in traditional teaching, interaction teaching focuses on students taking active part in the organization of every part of teaching, letting students participate in the whole process of teaching, to make them truly become the main part of teaching activities. At the same time, it needs to develop the main parts of teachers in teaching, to realize the doubleoriented communication and interaction between teachers and students, and students and students. It is a teaching method which bases on teacher-directing and student-directing is organized by the interaction between teachers and students, and the interaction between students and students, and the interaction between human beings and multi-medias.

Interaction teaching is put forward by Palincsar in 1982 at first. It gets further researches and development later. It is a teaching model which develops based on scaffolding teaching theory. Interaction teaching is under micro teaching scene, on multi-points freely cutting teaching plat, a teaching method with which the teaching of teachers and the studying of students communicate equally and interact autonomously around a certain question or topic. It has an important education value. Interaction teaching is a educational theory and strategy which is adjusted to generation. Interaction teaching focuses on students. Students autonomously participate in every part of teaching activities, so as to realizing the communication and interaction between teachers and students, and the communication and interaction between students and students.

Mayer(2001) has shown that it is useful to distinguish two views of learning: information acquisition and knowledge construction. In the information acquisition view learning involves adding information to the learner's memory. The instructor's job is to present information and the learners' job is to receive the information. A typical learning environment is non-interactive, such as a narrated animation or a textbook lesson. In contrast, in the knowledge construction view, learning involves building a mental representation. The leaner is a sense-maker who works to select, organize, and integrate new information with existing knowledge. According to a knowledge construction approach to learning, the goal of instruction is to guide the learner to actively make sense of the instructional materials(Mayer 2005c).

The so-called interaction teaching focuses on students, emphasizes the communication and interaction between teachers and students, the interaction of students' every cognitive activity, and emphasizes the combination of language input and output of students. In interactive teaching, the action of students is based on the inspiration of teachers. English teaching itself has extreme strong practicality and communication. Only by providing different forms of class 
activities to students can ensure their continuous learning interests. If teachers let students listen all the class in listening class, students can feel bored inevitably. Teachers should focus on students, setting from the reality to create colorful language communicating activities for students, to promote the combination of language input and output of students.

\section{APPLICATION}

\section{A. Interactive teaching is divided into three steps:}

1) Pre-listening: teachers firstly introduce the contents and backgrounds of listening materials, at the same time, design questions to help students understand the listening materials. In addition, choose some new language knowledge from listening texts and explain in detail to students.

2) Listening: play listening materials. During this process, teachers can still ask some questions about listening materials. Students can also ask any questions about listening materials, and teachers give answers. It is interaction between teachers and students. Of course, the answers of some questions can be gotten from the discussion of students.

3) Post-listening: in general, many listening exercises can be completed at this stage. In addition, developing some developing activities like role-play, debating, group-discussion and so on, can help students use target language more frequently and correctly. At last, teachers will evaluate and give feed-back according to the results of students' activities, in order to help students correct mistakes in time.

\section{B. The background of application of interactive teaching}

With the reform of CET4/6, the percentage of listening is becoming larger and larger. For example, the percentage of listening of 2004 is $20 \%$, the percentage of 2006 increased to $35 \%$, and in 2008 some college pilots, the percentage of listening even reached $70 \%$. Therefore, as the increasing trend of listening in CET4/6, students also gradually accept the importance of listening and positively do extra listening training. But the effects are not obvious; the scoring rate of students in listening tests is generally low. The phenomenon is related to many factors. Especially, in the long run, college English listening teaching mainly adopts traditional teaching methods which focus on teachers. And it is also called speaking all the class. Under this teaching method, teachers become the main role in teaching, while students are basically in passive state. The lack of emotional communication, and exchange of knowledge and information between students and teachers, leads to the separation of teaching and learning. With the rapid reform of foreign language teaching, foreign language teaching more and more emphasizes on the pattern of focusing on students. The teaching model will have a significant influence on foreign language teaching, because it will be adopted by more and more teachers[2].

\section{A case of application of interaction teaching method in college English listening teaching}

Interactive teaching emphasizes the interaction between teaching and studying. It has changed the traditional teaching method of focusing on teachers. The formal listening practice can be started after warming-up. At first, in order not to destroy the completeness of listening materials, teachers can let students listen to listening materials overall, thus, students can have a macro comprehension of listening materials. Then teachers can let group students discuss the material and guide them correctly, to make students have a deeply comprehension of the material and let students answer the questions about the material given by other students, to improve their communication ability. At last, teachers judge and give answers. It can't only excise students' logic reasoning ability, but also form the interaction between teachers and students. During the process, students become the body of teaching activities, while the teacher is only a director, a participator or a cooperator[2].

\section{The application of interactive teaching in class}

Interactive teaching focuses on the support and promoting of teachers and learners. In English teaching part, it mainly reflects the forms of pair work, group discussion, and debate and so on. In the beginning of interactive teaching, teachers are the conductor of teaching. They more and specifically show the use of all kinds of comprehension strategies. But with the development of teaching, teachers gradually guide students to use these strategies. With the improvement of students' learning level, teachers gradually guide students to use these strategies. With the improvement of students' learning level, teachers gradually improve requirements, until they can use these strategies independently. It reflects teaching control change from teachers to students dynamically. It is important to motivate and develop students' initiative. Interactive teaching is to adjust students' non-intelligence factors, such as interest, attitude, and motivation and learning strategies, to motivate students' learning potential and increase learning efficiency. After the involvement of interactive teaching, an article which seems to be boring and hard, not only can fully motivate students' passion of self-study and participation, but also cultivate students' co-work spirit in group activities, most importantly, students gradually master the learning methods of language and language culture in teacher-student interaction and student-student interaction.

\section{The DisADVANTAgES OF TRADITIONAL LISTENING} TEACHING AND THE ADVANTAGES OF INTERACTION LISTENING TEACHING

Interaction teaching has solved three factors affecting listening from three sources. The first is listeners' factor. The activity of listeners is improved largely. It changed the problem of listeners passively listening in traditional teaching. The second is speakers' factor. Teachers teach predicting skills, listening and reading skills to students. It greatly improves listening efficiency. The third is spreading medium and media factor. Input and output model is below. 


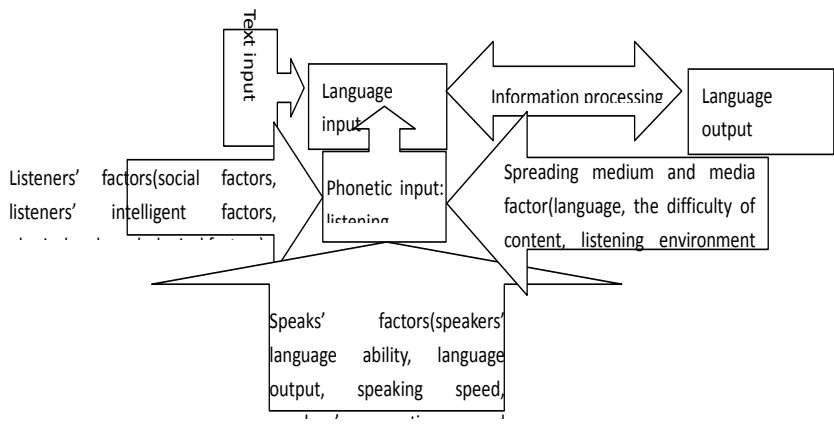

Fig. 1. The language input and output model.

\section{A. Listeners' and speakers' factors}

1) In phonetic: College English teachers make listeners, the learners of college English, master some basic phonetic knowledge, such as assimilation, liaison, ellipsis and so on. For example, /its'fa:re'wei/, the meaning is “it's far away". It is a common assimilation phenomenon in spoken English, so that the distraction of attention of listening exercisers in these details is avoided.

2) In vocabulary: vocabulary is divided into listening vocabulary and reading vocabulary. The so-called listening vocabulary is the amount of vocabulary which is recognized by ears not by eyes. The amount of listening vocabulary of our mother language is as much as reading vocabulary, or is even more than reading vocabulary, such as "artichoke", most people even if can't write it or have never learnt it before, they can judge it by common sense. But to most people, in English, listening vocabulary is much less than reading vocabulary. Therefore, many words which we can read, but when people speak them, we may think it for a while, or just do not know. It demands that college listening teachers focus on improving listening vocabulary of students, students' language reacting abilities, and the comprehension of certain listening materials.

3) In grammar and discourse: the comprehension of listening materials of students not only involves the vocabulary and grammar structure of materials, but involves its discourse information and related culture background knowledge. In order to understand English by listening, students must enlarge their knowledge, know some backgrounds and customs about English countries. Otherwise, the listening of students can meet some unpredictable obstacles, for example, many students complain that when they do listening exercises they can understand the meaning of every sentence but they can't understand the main point of article. There are many causes, but the more common cause is when students master enough vocabulary and complete grammar structure and get higher comprehension ability, but they are not familiar to the large amounts of background knowledge related to European and American culture. In general, students can easily master familiar contents, but it is hard for them to master relatively unfamiliar contents. For example, there are two articles of same difficulty, one is about Chinese traditional culture, the other is about Christian. In comparison, and it is easier for the students to understand the former article.

There are many factors that can affect listening, such as the language ability of speakers, tones, speaking speed, culture backgrounds and so on.

\section{B. spreading medium and media factor}

In listening lessons, speakers send message by tapes or CDs and students are listeners. The choosing of listening materials has much to do with developing students' listening skills and developing students' comprehensive mastering of language. Listening is abstract, different from reading and writing. The process of listening is to know, recognize and understand information. In listening training, because time is limited, afraid of making mistakes, or not understanding, students often feel worried and afraid, and it affects the effects of listening directly. The anxious and nervous emotion of students hindered the improvement of their listening level. For example, some students feel nervous as soon as they meet long sentences and strange vocabulary. Therefore, in listening lessons, teachers should try their best to create a relaxing and enjoying teaching atmosphere, change the traditional teaching model of listening to the record---answering questions---checking answers, and try to reduce students' anxiety. When they choose listening materials, teachers should consider the interests of materials and comprehension abilities of students, apart from difficulty. If the difficulty of materials is beyond the listening ability of students, it will lead to frustration, the declining of learning interests and negative attitude in listening exercising. Under this situation, teachers should choose interesting listening materials of equal difficulty(such as the latest news, interesting stories and so on). In addition, the forms of listening materials should be diverse, and the contents should be abundant, except listening tapes, there should be CDs, video tapes and so on. Students can watch except listening. Let students listen and watch with a pleasant feeling in a relaxing environment. Their anxiety will be removed, their confidence is improved and their interest of learning is motivated. Their memory and impression of language materials will be formed while they are understanding the language materials[3]. 


\section{The CASE OF INTERACTIVE Listening TEACHING}

A table is used to describe the process of interactive teaching[4].

TABLE I. THE PROCESS OF INTERACTIVE TEACHING

\begin{tabular}{|c|c|}
\hline $\begin{array}{l}\text { Teaching } \\
\text { content: }\end{array}$ & $\begin{array}{l}\text { New horizon college English viewing, listening and } \\
\text { speaking (Book one) Unit1 }\end{array}$ \\
\hline Teaching time: & I, II parts and culture talk totally cost 100 minutes. \\
\hline $\begin{array}{l}\text { Teaching } \\
\text { procedures: }\end{array}$ & $\begin{array}{l}\text { Firstly, scan the teaching goals of I,II parts displayed } \\
\text { on Focuses with students. And require students to } \\
\text { summarize the main content. The first two parts are } \\
\text { arranged as listening exercises. The author combines } \\
\text { listening with speaking, and let students practice } \\
\text { speaking after they have understood. }\end{array}$ \\
\hline Warming-up: & $\begin{array}{l}\text { After guiding students to know and think the title of } \\
\text { enrolling, the teacher plays the record, and fills the } \\
\text { blanks to question the students. Teacher plays the } \\
\text { record again and again until all the students can come } \\
\text { up with the answers of questions. }\end{array}$ \\
\hline Conversation: & $\begin{array}{l}\text { Leave time to students to scan the listening materials. } \\
\text { Long conversation costs } 90 \text { seconds and short } \\
\text { conversation costs about } 30 \text { seconds. After playing } \\
\text { the short conversation, the teacher repeats the } \\
\text { question: Why does the woman enjoy living on } \\
\text { campus? And ask the students to repeat what they } \\
\text { have listened about the answers of questions. The } \\
\text { teacher does not stop playing the record until all the } \\
\text { answers of questions are given. And then the teacher } \\
\text { plays the long conversation. Ask and answer the } \\
\text { questions[5]. }\end{array}$ \\
\hline Passage: & $\begin{array}{l}\text { The students are asked to listen to the speaker and } \\
\text { complete the paragraph. And they are asked to listen } \\
\text { to it again and check their answers. }\end{array}$ \\
\hline Movie: & $\begin{array}{l}\text { Firstly, the teacher uses English to introduce the } \\
\text { background knowledge to the students and pays } \\
\text { attention to the reaction of the students and adjusts } \\
\text { the speaking speed. After playing several times, the } \\
\text { students are asked to role-play in groups. }\end{array}$ \\
\hline Culture talk: & $\begin{array}{l}\text { After listening to the model dialog, the students are } \\
\text { asked to role-play it with their partner. }\end{array}$ \\
\hline
\end{tabular}

\section{REFERENCES}

[1] Liu Lihua, li-xia tang. The application of interactive teaching in higher vocational college oral English teaching [J]. Journal of vocational and technical education. 2010 (31).

[2] zhang jiao. Introduction to college English listening teaching interactive [J]. Journal of literary education. 2013 (3).

[3] jun-wei zhang. Talk about the application of interactive teaching in college English listening course [J]. Journal of wuhan vocational and technical college journal. 2007 (6).

[4] Yang Qiong. Examples of interactive's college English listening teaching and reflection on $[\mathrm{J}]$. Journal of yunnan normal university business school. 2012.

[5] Xu Zhong. New horizon college English audio-visual course 1 [M]. Foreign language teaching and research press. 2004.

[6] Nunan, David. Research Methods in Language Learning. Shanghai: Shanghai Foreign Language education Press, 2002. 